\title{
Correlation between Church Digital Ministry and Semarang Baptist Youth's Spirituality
}

\author{
Yesaya Bangun Ekoliesanto, ${ }^{1 *}$ Samuel Agus Santoso, ${ }^{2}$ Ayin Claudia ${ }^{3}$ \\ ${ }^{1,2,3}$ Sekolah Tinggi Teologi Baptis Indonesia \\ *email: yesayaekoliesanto@stbi.ac.id
}

\begin{abstract}
The spirituality of today's young generation is very prone to be bad. The church needs to serve the younger generation in a way acceptable to them. This study aims to see the correlation between church digital ministry and the spirituality of Baptist youths throughout the city of Semarang. This research used quantitative approach with survey research methods. It shows that the Baptist churches' digital ministries were in the medium category and the Baptist youth's spirituality was in the moderate category, while digital ministry of the churches correlated strongly and positively to their youth's spirituality.
\end{abstract}

Key words: Digital Ministry, Spirituality, Youth, Baptist Church

Article History:

Submitted: Sept. 11, 2021

Revised: Jan. 19, 2022 (c) (i) (2)

This is an open access article under the CC BY-SA license

\section{INTRODUCTION}

Nowadays, Indonesia is in a period of demographic bonus, a condition in which the population within productive age range (15-64 years old) are greater than those outside the range (Bappenas, 2017, p. 1). This means that in churches across Indonesia, there is a significant number of parishioners within this age range, indicated by their tech-savviness. A study by We Are Social shows that this generation uses nearly eight hours a day to access the internet (Kemp, 2020, p. 22). It is also mentioned that of 10 favorite apps, no spirituality apps were found. Besides, the growth of secular apps in present is massive and they enrich the choice of youths in spending their time surfing the virtual world/internet. The immense dependence to the internet became higher in intensity during the emergence and spread of the Covid-19 pandemic in early 2020 (Levani et al., 2020, p. 104). This disease spreads rapidly and paralyzes global economy. Indonesia themselves started to suffer the impacts of the pandemic between March of the same year, when the government started to advise people to socially distance and do all activities from home (Dirjen Pencegahan dan Pengendalian Penyakit, 2020).

This condition also affected Church activities. All Church activities were and remain closed due to government order and in reflection of Covid-19 cluster in South Korea that started from a church service which caused approximately 5000 people to be infected (News, 2020). Therefore, either willingly or not, the Church needed to change its pattern of ministry to be based on technology, including the character, approach, \& culture of service, fellowship, and others (Darmawan et al., 2021). This is important to do because ministry has an important role in Christian spirituality (Zaluchu $\&$ Ekoliesanto, 2021, p. 9). For some churches, this did not become a problem since they had been wellequipped with adequate infrastructure and resources. However, for the vast majority of churches with no experience of online ministry, it became a huge problem because adapting to this situation required new resources, such as equipments, internet network installations, resources, and other technical matters. 
Many Christian youths today participate in religious/Church activities through the use of technology. This technology enables the Church to minister without worrying the constraints of time and space (Okselviana \& Hastjarjo, 2016, p. 17). However, David Kinnaman of Barna Group (in Budijanto, 2018) stated that seven out of 10 younger generations of church members worshipping weekly every Sunday would leave their Church when they are 18 to 30 years old (Irawan et al., 2018, p. 4). This is possible due to inability of the Church to reach their youths through the use of technology (Camerling et al., 2020). It is further worsened by the present condition of the pandemic. Youths who mostly still need spiritual guidance become uncontrollable due to the lack of time to directly meet in the Church. Online Bible study attempts by some churches also face various hindrances (Lumbantobing \& Widodo, 2021, p. 44), which also impacts the youth's spirituality. Pastors/ youth pastors also face difficulties to hold proper guidance sessions because of their lack of technological abilities.

Based on the researcher's observation during the early days of the pandemic in 2020, church multimedia teams that should become the necessary bridge to minister the parishioners, especially the youths, were still a rarity among churches observed, especially within the confines of Baptist churches in the city of Semarang. The researcher opined that this condition was caused by the lack of digital mindset from the pastors to pursue their churches' lag of technological implementation in Church activities. Multimedia teams at that time were mainly concerned only for projecting hymn slides in their churches' walls.

In April 2020, the researcher conducted preliminary studies in several Baptist churches within Baptist Regional Convention of Northern Central Java, including the city of Semarang. A phenomenon in this area was found, in which the churches faced difficulties in holding online ministries due to the lack of facilities and human resources. This caused many youth parishioners to not be properly ministered which caused lessening spirituality among them.

Based on the background aforementioned, this research aims to: 1) understand the level of digital ministries of Baptist churches throughout Semarang city; 2) understand the level of spirituality of Baptist youths throughout Semarang city; and 3) understand the strength of correlation between digital ministries of Baptist churches throughout Semarang city to their youth's spirituality.

The topic seek to continue the research on the Church's ministerial priority during the pandemic through digital platform use (Sastrohartoyo et al., 2021). Besides, the research also endeavor to strengthen the research by (Hutahaean et al., 2020) on the phenomenological review of at-home worship services.

\section{METHOD}

This research used quantitative approach with survey method. Data for this research were collected in situ by using Google forms-powered online questionnaire targeting 500 youths in 30 Baptist churches throughout Semarang city. This research was conducted starting from November 2020 to June 2021.

In collecting research data, questionnaire was chosen due to the existing assumption that research subjects are the ones that can understand themselves most. Therefore, their statements for this research were considered true and believable (Walgito, 1986, pp. 25-26). In determining question structure within questionnaire, the researcher used Likert scale which can measure behavior, opinion, and understanding of an individual or a group of people on social phenomena. The scale's usage can describe variables to be measured to become measurable indicators.

Data sampling in this research used simple random sampling technique, in which samples were randomly selected by the researcher (Zaluchu, 2018). This method was chosen since the population was considered homogenous (Sugiyono, 2012). In this method, all population members had the 
opportunity to be chosen as samples (Subagyo, 2004). Thirty members of population were isolated from research population for use of instrument trial which reduced total research population to 470 people. The samples determined, based on Krejcie \& Morgan table with 5\% margin of error, was 210 people (Sasmoko, 2005, p. 256).

\section{Research Instrument Trial}

\section{Validity Test}

Material validity was tested by first proposing validity test request to three experts. It was found that there were 38 valid questions and three invalid questions based on the validity test. meanwhile, construct validity was tested by instrument trial. Zaluchu (2018) gave a guideline that in order to achieve similar curve to normal curve as a comparison indicator, thirty trial respondents are needed. Instrument test was conducted through correlation test between instrument scores by using Pearson Product Moment formula (Riduwan, 2010, p. 98). In determining whether a question item was deemed valid, correlation coefficient significance test was conducted with $5 \%$ significance rate. $\mathrm{A} \mathrm{r}_{\text {crit }}$ of 0.355 was obtained from $\mathrm{n}=30$ and $5 \%$ significance rate, meaning that if correlation coefficient of each item was found to be greater than $r_{c r i t}$, the item was considered valid, vice versa. Construct validity test result shows that all question items had greater $r_{\text {stat }}$ than $r_{\text {crit }}$ and thus were considered valid.

\section{Reliability Test}

Reliability test was needed to observe consistency of measuring instrument designed (Zaluchu, 2018). Cronbach's alpha in SPSS 26 software was used to measure the instrument's reliability index. The result shows that Cronbach's alpha of 0.939 was obtained, meaning that the statement items were of high reliability.

\begin{tabular}{cc}
\hline \multicolumn{2}{c}{ Reliability Statistics } \\
\hline Cronbach's Alpha & N of Items \\
\hline .939 & 38 \\
\hline
\end{tabular}

Table 1 . Reliability test result

\section{Final research instrument}

Final research instrument was the instrument used in the research after having been tested for its validity and reliability. Based on the results aforementioned, the final instrument produced were to have 38 question items with 0.939 measurement reliability index. After the data on the correlation between digital church ministry and spirituality of Semarang Baptist youths were collected through questionnaire, they were tabulated and analyzed for conclusion.

\section{RESULT AND DISCUSSION}

\section{Data description}

The post-trial questionnaire was distributed to 210 samples of research population through Google forms. All questionnaires were completed, with two of them were found to be not meeting criteria due to unsuitable data. Therefore, 208 sample data were used.

\section{Description of variable of Baptist Church Digital Ministry $(X)$ \\ Of 208 sample data, theoretical score} between 22 and 70 was obtained, with mean of 50.38 , median of 51, and standard deviation of 10.484 .

\section{Description of variable of Baptist Youth Spirituality $(Y)$}

Of 208 sample data, theoretical score between 24 and 120 was obtained, with mean of 80.12 , median of 80 , and standard deviation of 17.575 .

\begin{tabular}{lll}
\hline Item & Digital Ministry & Spirituality \\
\hline Mean & 50.38 & 80.12 \\
\hline Median & 51 & 80 \\
\hline Standard Deviation & 10.484 & 17.575 \\
\hline Minimum & 22 & 24 \\
\hline Maximum & 70 & 120 \\
\hline Count & 208 & 208 \\
\hline
\end{tabular}

Table 2. Data description 


\section{Results}

Baptist Church Digital Ministry (X)

\begin{tabular}{|c|c|c|c|c|}
\hline & & & Statistic & $\begin{array}{l}\text { Std. } \\
\text { Error }\end{array}$ \\
\hline \multirow{13}{*}{$\begin{array}{l}\text { Church } \\
\text { digital } \\
\text { ministry }\end{array}$} & \multicolumn{2}{|c|}{ Mean } & 50.38 & 0.727 \\
\hline & \multirow{2}{*}{$\begin{array}{c}95 \% \\
\text { Confidence } \\
\text { Interval for } \\
\text { Mean } \\
\end{array}$} & $\begin{array}{l}\text { Lower } \\
\text { Bound }\end{array}$ & 48.95 & \\
\hline & & $\begin{array}{l}\text { Upper } \\
\text { Bound }\end{array}$ & 51.81 & \\
\hline & \multicolumn{2}{|c|}{$5 \%$ Trimmed Mean } & 50.53 & \\
\hline & \multicolumn{2}{|c|}{ Median } & 51.00 & \\
\hline & \multicolumn{2}{|c|}{ Variance } & 109.908 & \\
\hline & \multicolumn{2}{|c|}{ Std. Deviation } & 10.484 & \\
\hline & \multicolumn{2}{|c|}{ Minimum } & 22 & \\
\hline & \multicolumn{2}{|c|}{ Maximum } & 70 & \\
\hline & \multicolumn{2}{|c|}{ Range } & 48 & \\
\hline & \multicolumn{2}{|c|}{ Interquartile Range } & 15 & \\
\hline & \multicolumn{2}{|c|}{ Skewness } & -0.250 & 0.169 \\
\hline & \multicolumn{2}{|c|}{ Kurtosis } & -0.461 & 0.336 \\
\hline
\end{tabular}

Table 3. X variable descriptive statistic test

Total category $(\Sigma \mathrm{k})$ was defined into 5 categories of Very Low, Low, Medium, High, and Very High. Interval score was obtained by using formula as follows.

$\mathrm{i}=\mathrm{R} / \Sigma \mathrm{k}=48 / 5=9.6$ (rounded up to 10 )

$\mathrm{i}=$ interval $\mathrm{k}=$ category $\mathrm{R}=$ Range

In order to produce five-category table, the formula below was used.

i. $\mathrm{k} \geq \mathrm{R}+1$

$10 \times 5 \geq 48+1$

\section{$50 \geq 49 \rightarrow$ suitable}

Since the equation aforementioned was more-or-less suitable, the minimum score was unchanged. Based on the findings abovementioned, digital ministries of Baptist churches throughout Semarang city were found in Medium category with 48.95 lower bound and 51.81 upper bound within 44-54 interval. The lower and upper bounds of 48.95 to 51.81 were calculated by analyzing the data through confidence interval on $5 \%$ significance rate.

\section{Respondents'Spirituality (Y)}

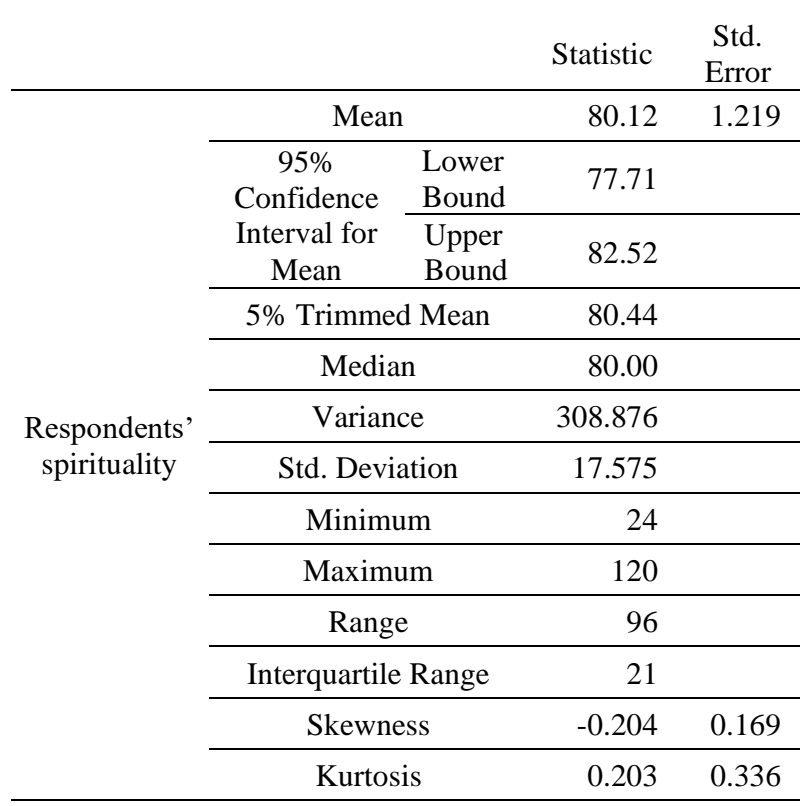

Table 4. Y variable descriptive statistic test

Total category $(\Sigma \mathrm{k})$ was defined into 5 categories of Very Low, Low, Medium, High, and Very High. Interval score was obtained by using formula as follows.

$\mathrm{i}=\mathrm{R} / \Sigma \mathrm{k}=96 / 5=19.2$ (rounded up to 20$)$

$\mathrm{i}=$ interval $\mathrm{k}=$ category $\mathrm{R}=$ Range

In order to produce five-category table, the formula below was used.

i. $\mathrm{k} \geq \mathrm{R}+1$

$20 \times 5 \geq 96+1$

$$
100 \geq 97 \rightarrow \text { suitable }
$$

Since the equation aforementioned was more-or-less suitable, the minimum score was unchanged. Based on the findings abovementioned, the level of spirituality of the respondents was found to be included in the Medium category with 77.71 lower bound and 82.52 upper bound within $66-86$ interval. The lower and upper bounds of 77.71 and 82.52 were calculated by analyzing the data through confidence interval on $5 \%$ significance rate. Therefore, based on this finding, the spirituality of youths in Baptist churches throughout Semarang city was found in Medium category. 


\section{Correlation between $X$ and $Y$}

The correlation testing through SPSS 26 software gave a result as follows.

\begin{tabular}{|c|c|c|c|}
\hline & & $\begin{array}{l}\text { Church } \\
\text { digital } \\
\text { ministry }\end{array}$ & Spirituality \\
\hline \multirow{3}{*}{$\begin{array}{l}\text { Church digital } \\
\text { ministry }\end{array}$} & $\begin{array}{c}\text { Pearson } \\
\text { Correlation } \\
\end{array}$ & 1 & $.702^{* *}$ \\
\hline & Sig. (2-tailed) & & .000 \\
\hline & $\mathrm{N}$ & 208 & 208 \\
\hline \multirow{3}{*}{$\begin{array}{l}\text { Spirituality of } \\
\text { Baptist youths } \\
\text { throughout } \\
\text { Semarang city }\end{array}$} & $\begin{array}{c}\text { Pearson } \\
\text { Correlation }\end{array}$ & $.702^{* *}$ & 1 \\
\hline & Sig. (2-tailed) & .000 & \\
\hline & $\mathrm{N}$ & 208 & 208 \\
\hline Model & R Square & $\begin{array}{l}\text { Adjusted R } \\
\text { Square }\end{array}$ & $\begin{array}{c}\text { Std. Error } \\
\text { of the } \\
\text { Estimate }\end{array}$ \\
\hline $.702^{\mathrm{a}}$ & .493 & .491 & 12.542 \\
\hline
\end{tabular}

Table 5. X-Y variable correlation test

Based on the table aforementioned, significance value was found to be 0.000 , less than 0.05 , meaning that correlation between $\mathrm{X}$ and $\mathrm{Y}$ variables was found. Correlation coefficient value was discovered to be 0.702 , a positive value, meaning that the correlation was positive and the more valuable $\mathrm{X}$ variable is, the more valuable $\mathrm{Y}$ variable will be. This value was also found to be within the range of $0.60-0.799$ referring to the coefficient correlation interpretation guidelines, meaning that $\mathrm{X}$ and $\mathrm{Y}$ variables were strongly correlated. Determination coefficient, as signified by adjusted Rsquare was found to be 0.491 , showing that the influence of Baptist churches' digital ministry (X) to the spirituality of Baptist youths throughout Semarang city (Y) was $49.1 \%$, while the other $50.9 \%$ were sourced from other factors not included in this research's variables. Therefore, based on these findings, it is understood that the digital ministries of Baptist churches throughout Semarang city correlate strongly and positively to their youth's spirituality.

\section{Discussion}

\section{Baptist Church's Digital Ministry $(X)$}

The Church needs to put media ministry into operation due to the vast recent technological development (Camerling et al., 2020). The grace that God gives in this generation through technology needs to be maximized to reach as many people as possible. God's mission should be able to be translated by the Church of this time (Afandi, 2018). Reformation of youth ministries is important to be conducted immediately, so that the younger generation can be reached by the Church for the glory of God (Sitompul, 2017, p. 15).

Ministries within the Church are inseparable from the role of its leadership. Church leaders need to be ready to enter a digitalized world that might be new for them. However, the eternal values of the Word of God needs to be unchanged (Ronda, 2016, p. 197). This becomes a separate challenge to the leaders. Church leaders need to become examples in their spiritual and daily life (Arisandie, 2021, p. 74). The youth need to see and feel for themselves the presence of their leaders within their world.

The Baptist church itself is presently in a period of ministry transition, signified by the gradual adoption of modern technology for ministry development, including development of a child education website anak (Muryawati \& Ismanto, 2020, p. 189) and adaptation of online Sunday school in several churches (Karnawati \& Mardiharto, 2020).

The digital ministries of Baptist churches throughout Semarang city were found to be included in the Medium category. Based on the respondents' questionnaire answers, mean of 50.38 was found, with maximum and minimum scores of 70 (included in the Very High category) and 22 (included in the Very Low category) respectively. The significant gap between the scores was possibly due to the difference in adaptation process between churches. One congregation might be quick to adapt to the conditions caused by the pandemic by initiating online ministries, but another might feel forced and consequently was slower to do so (Teng \& Margaret, 2020). A survey by Bilangan Research Center shows that a majority of churches adapted to the pandemic conditions by holding digital ministries (Irawan, 2021). 


\section{Respondents'Spirituality (Y)}

The spirit to build spiritual life in the midst of Industrial Revolution 4.0 is set alight by the correct interpretation of the Bible (Katarina \& Darmawan, 2019). The correct concept will bring one to a correct growth of spirituality.

The spirituality of respondents found to be included in the Medium category. The technological savviness that church leaders might lack is possible to hinder the youth's spiritual growth due to the lack of proper care. On the other hand, however, this creates the opportunity to start a more active youth involvement in the Church ministries, which can have a positive impact to their spirituality. Michael Teng stated that ministries of the Church during the pandemic should initiate to open the rooms for involvement the laity (Teng \& Margaret, 2020). Social change is the challenge that Christian leaders and educators must answer (Harmadi \& Jatmiko, 2020). Online church fellowships that the youth start to participate, including prayer hours, KPW (cell groups), and PKMB (Baptist youth fellowship) can become the ways to minister to them. in addition, church WhatsApp groups are heavily utilized by church leaders to ensure the level of their parishioners' spirituality through the forwarding of various devotionals and Bible verses in the chats.

\section{$X-Y$ Correlation}

Result shows that the correlation between $\mathrm{X}$ and $\mathrm{Y}$ variables was found to be 0.702 (included in the Strong category) while the determination coefficient (adjusted r-square) was found to be 0.491 , meaning that the influence of church digital ministries $(\mathrm{X})$ to the spirituality of Baptist youth

\section{REFERENCES}

Afandi, Y. (2018). Gereja Dan Pengaruh Teknologi Informasi "Digital Ecclesiology." FIDEI: Jurnal Teologi Sistematika Dan Praktika, 1(2), 270-283. https://doi.org/10.34081/fidei.v1i2.12

Arisandie, T. P. (2021). Potret Kekristenan Pada Suku Dayak Pesaguan Di Provinsi Kalimantan throughout Semarang city (Y) amounted to $49.1 \%$ while the other $50.9 \%$ came from other factors unincluded in this research's variables, such as family, school, social environment (Irawan et al., 2018), and outside-church spiritual ministries. There are various ministries by parachurches found freely in various virtual platforms. The $X-Y$ correlation found in this research was positive, meaning that the more digital ministries by churches are held, the higher the level of spirituality of their youth will be.

It is in line with (Afandi, 2018) that digital media will become an inseparable part within the Church to answer the challenges of time. In addition, (Darmanto, 2020, p. 41) also opined that ministry community can have a positive impact on the youth's reception to "come to Jesus", in which one of the ministry community with most interest is digital ministry.

\section{CONCLUSION}

Digital ministry becomes a need the Church today cannot ignore. Special care is needed by this field, since the pandemic creates an unavoidable situation in which all church activities are held online. Digital ministry done well by the Church strongly and positively correlates to its youth's level of spirituality. Youths as tech-savvy individuals need to be ministered and to be actively involved in digital ministry in order to ever grow their spirituality which makes them unshakable by the world's desires. Further research is needed on the effectiveness of digital ministry to youth spirituality and the impact of digital ministry to church members in general.

Barat. Jurnal Ilmiah Religiosity Entity Humanity (JIREH). https://doi.org/10.37364/jireh.v3i1.58

Bappenas. (2017). Siaran Pers Bonus Demografi 2030-2040.

Budijanto, B. (2018). Spiritualitas Generasi Muda dan Gereja. In B. Budijanto (Ed.), Dinamika 
Spiritualitas Generasi Muda Kristen Indonesia. Bilangan Research Center.

Camerling, Y. F., Lauled, M. C., \& Eunike, S. C. (2020). Gereja Bermisi Melalui Media Digital Di Era Revolusi Industri 4.0. Visio Dei: Jurnal Teologi Kristen, 2(1), 1-22. https://doi.org/10.35909/visiodei.v2i1.68

Darmanto, D. (2020). Memahami Budaya Kaum Muda Sebuah Misiologi Baru di Jagad Maya. SANCTUM DOMINE: JURNAL TEOLOGI, 7(1), 25-46. https://doi.org/10.46495/sdjt.v7i1.42

Darmawan, I. P. A., Giawa, N., Katarina, K., \& Budiman, S. (2021). COVID-19 Impact on Church Society Ministry. International Journal of Humanities and Innovation (IJHI), 4(3), 93-98. https://doi.org/10.33750/ijhi.v4i3.122

Dirjen Pencegahan dan Pengendalian Penyakit, K. R. (2020). Pedoman Pencegahan dan Pengendalian Coronavirus Disease (Covid19) (Revisi Ke). P2P Kemenenterian Kesehatan RI.

Harmadi, M., \& Jatmiko, A. (2020). Pembelajaran Efektif Pendidikan Agama Kristen Generasi Milenial. PASCA: Jurnal Teologi Dan Pendidikan Agama Kristen, 16(1), 62-74. https://doi.org/10.46494/psc.v16i1.72

Hutahaean, H., Silalahi, B. S., \& Simanjuntak, L. Z. (2020). Spiritualitas Pandemik: Tinjauan Fenomenologi Ibadah Di Rumah. Evangelikal: Jurnal Teologi Injili Dan Pembinaan Warga Jemaat, 4(2), 234. https://doi.org/10.46445/ejti.v4i2.270

Irawan, H. (2021). Pelayanan dan Dinamika Gereja Selama Pandemi Covid-19.

Irawan, H., Yahya, K., Tanbunaan, G. I., Arthanto, H. G., Liang, T. P., Suhendra, J., \& Budijanto, B. (2018). Dinamika Spiritualitas Generasi Muda Kristen Indonesia (B. Budijanto (ed.)). Yayasan Bilangan Research Center.

Karnawati, K., \& Mardiharto, M. (2020). Sekolah Minggu Masa Pandemi Covid 19: Kendala, Solusi, Proyeksi. Didache: Journal of
Christian Education, 1(1), 13-24. https://doi.org/10.46445/djce.v1i1.291

Katarina, K., \& Darmawan, I. P. A. (2019). Implikasi Alkitab dalam Formasi Rohani pada Era Reformasi Gereja. EPIGRAPHE: Jurnal Teologi Dan Pelayanan Kristiani, 3(2), 8193.

https://doi.org/10.33991/epigraphe.v3i2.85

Kemp, S. (2020). Indonesia Digital Report 2020. Digital 2020: Indonesia. https://datareportal.com/reports/digital-2020indonesia

Levani, Y., Hakam, M. T., \& Utama, M. R. (2020). Potensi Adiksi Penggunaan Internet pada Remaja Indonesia di Periode Awal Pandemi Covid 19. Hang Tuah Medical Journal. https://doi.org/10.30649/htmj.v17i2.437

Lumbantobing, T. S. P., \& Widodo, P. (2021). Online Bible Study During a Pandemic: Challenges, Solutions, and Opportunities. GRAFTA: Journal of Christian Religion Education and Biblical Studies, 1(1).

Muryawati, M., \& Ismanto, B. (2020). Pengembangan Website "Sayang Anak Indonesia" Gabungan Gereja Baptis Indonesia. Kurios. https://doi.org/10.30995/kur.v6i2.139

News, B. (2020). Covid-19 di Korsel: Apa yang kita ketahui tentang Sarang Jeil, gereja yang jadi klaster baru virus corona di Korea Selatan.

Okselviana, A. D., \& Hastjarjo, S. (2016). Penggunaan New Media Sebagai Media Komunikasi Jemaat GBI Keluarga Allah Solo. Jurnal Komunikasi Massa, 1.

Riduwan. (2010). Belajar Mudah Penelitian (Akdon (ed.); 6th ed.). Alfabeta.

Ronda, D. (2016). Pemimpin dan Media: Misi Pemimpin Membawa Injil Melalui Dunia Digital. Jurnal Jaffray. https://doi.org/10.25278/jj71.v14i2.210

Sasmoko. (2005). Metode Penelitian Pengukuran dan Analisis Data. HITS.

Sastrohartoyo, A. R., Abraham, R. A., Haans, J., \& Chandra, T. (2021). The Priority of the 
Church's Ministry during a Pandemic. Evangelikal: Jurnal Teologi Injili Dan Pembinaan Warga Jemaat, 5(2), 164-174. https://doi.org/10.46445/EJTI.V5I2.336

Sitompul, R. P. (2017). Pelayanan Pemuda di Era Teknologi Digital. Jurnal Antusias.

Subagyo, A. B. (2004). Pengantar Riset Kuantitatif \& Kualitatif. Kalam Hidup.

Sugiyono. (2012). Metode Penelitian Kuantitatif, Kualitatif dan $R \& D$. Penerbit Alfabeta Bandung.

Teng, M., \& Margaret, C. (2020). Sketsa Pelayanan Gereja Sebelum, Selama, dan Sesudah Masa Pandemi COVID-19. Veritas: Jurnal Teologi
Dan Pelayanan, 19(2), 201-213. https://doi.org/10.36421/veritas.v19i2.432

Walgito, B. (1986). Bimbingan dan Penyuluhan Sekolah. FPUGM.

Zaluchu, S. E. (2018). Sistematika dan Analisis Data Riset Kuantitatif. Golden Gate Publishing.

Zaluchu, S. E., \& Ekoliesanto, Y. B. (2021). Daud Meloncat-loncat dan Menari-nari: Aspek Teologis Bahasa Tubuh dalam Ibadah Kristiani. KHARISMATA: Jurnal Teologi Pantekosta.

https://doi.org/10.47167/kharis.v3i2.60 